\title{
Influence of Timing of Sucrose Meal Feeding and Physical Activity on Plasma Triacylglycerol Levels in Rat
}

\author{
Masashige SUZUKI, Naohiko HASHIBA, and Takeshi KAJUU ${ }^{1}$ \\ Laboratory of Biochemistry of Exercise and Nutrition, Institute \\ of Health and Sports Science, University of Tsukuba, \\ Sakura-mura, Niihari-gun, Ibaraki 305, Japan
}

(Received October 5, 1981)

\begin{abstract}
Summary The present study was undertaken to determine whether the timing of sucrose meal feeding relative to periods of physical activity affects plasma triacylglycerol (TG) levels in rats. Animals were daily mealfed on a basal diet and a $35 \%$ sucrose diet for 10 weeks. Meal times were at $08.00-09.00 \mathrm{hr}$ and $21.00-22.00 \mathrm{hr}$. Voluntary running in wheels was allowed between $22.00-08.00 \mathrm{hr}$, but was restricted from 08.00 to $22.00 \mathrm{hr}$. The sucrose diet was given at the morning meal time to one group (M-S eaters) and at the evening meal time to another group (E-S eaters). The timing of the sucrose meal did not have any influence on consumption of either of the two diets, physical activity, weight gain, or the weight of several organs and tissues. Plasma TG, however, was significantly higher in the M-S eaters than in the E-S eaters. Lipoprotein lipase activity of several tissues was not affected by the timing of the sucrose meal. The Triton-induced increase in fasting plasma TG was significantly higher after the sucrose meal than after the basal meal regardless of the timing of the sucrose diet. The TG accumulation rate during the physically inactive period was significantly greater in the M-S eaters than in the E-S eaters, while during the physically active period it was equal in both groups. These results suggest that the effect of sucrose feeding on plasma TG may be conditioned by the timing of sucrose feeding and rats' physical activity. Key Words physical activity, sucrose feed-timing, plasma TG, TG production, lipoprotein lipase, rat
\end{abstract}

Human beings generally work during the day and rest at night, and usually consume two or three meals a day. It is well known that feeding pattern and exercise influence the nutrition of men and animals. Several papers have reported on the nutritional effects of the timing of nutrient feeding in relation to physical activity (16).

1 鈴木正成, 橋場直彦, 加重 剛 
The present study was designed to investigate if any difference might occur in plasma TG levels in rats given a hyperlipemic nutrient, sucrose, with different timings relative to periods of physical activity. Romsos and Leveille (5) failed to produce significant results on the nutritional effect of meal-timing by using rats fed in the usual type of cage, this seeming to be due to the relatively small physical activity and low energy expenditure of rats. In this study, cages with revolving wheels were utilized to give rats a certain rhythm of physical activity and resting. Furthermore, two animal groups were alternately fed on a control diet and a sucrose-containing diet at different times of day.

The results show that the difference in the timing of sucrose feeding in relation to the absence or presence of physical activity after sucrose feeding alters plasma TG levels. This seems to be occurred through the effect of physical activity on hepatic-intestinal TG production.

\section{EXPERIMENTAL}

The outline of the feeding schedules is shown in Fig. 1. Two experiments were

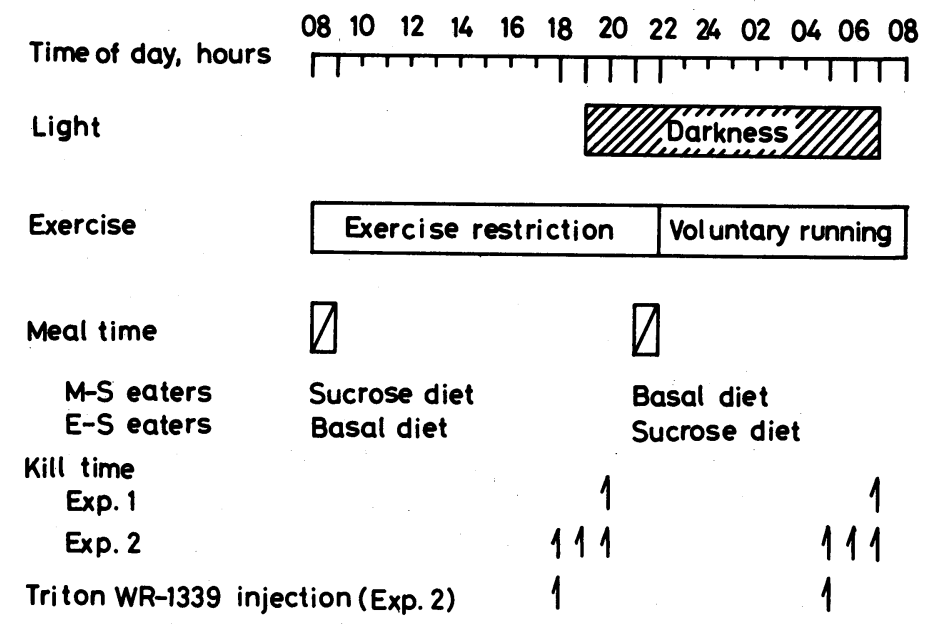

Fig. 1. Feeding and experimental schedules for experiments 1 and 2. Twenty male rats (10 rats respectively for M-S eaters and E-S eaters; experiment 1) and 60 male rats (30 rats for each group; experiment 2) were individually housed in cages with revolving wheels. They were daily alternately meal-fed on a basal diet and a $35 \%$ sucrose diet for 10 weeks following 2 weeks of adaptation to meal-feeding on the basal diet twice a day. Voluntary running was allowed only between $22.00-08.00 \mathrm{hr}$ throughout the 12 weeks of the meal-feeding period. At the end of the feeding period, the rats were killed one hour before each meal time in experiment 1 , or were intravenously injected with Triton WR-1339 at $05.00 \mathrm{hr}$ or at $18.00 \mathrm{hr}$ and then killed one or two hours after injection in experiment 2 . Animals without Triton were killed at $05.00 \mathrm{hr}$ and at $18.00 \mathrm{hr}$ and used as controls in experiment 2. 
conducted utilizing three-week-old male JCL-SD rats (Japan CLEA Inc., Tokyo) initially. The lights in the temperature-regulated room $\left(23 \pm 2^{\circ} \mathrm{C}\right)$ were on from 07.00 to $19.00 \mathrm{hr}$. Rats were housed individually in rodent activity cages and allowed voluntary running by having access to revolving wheels attached outside the living cages. The voluntary running of all animals was restricted from 08.00 to $22.00 \mathrm{hr}$ by closing a gate between the revolving wheel and living cage. The number of revolutions was recorded by a digital counter on each cage. To determine the hourly rhythm of voluntary running activity, in five of these cages, digital electronic counters were automatically photographed every one hour by a camera with an auto-film rolling system. Rats were automatically fed via "Suzuki-Imamura's Automated Feeding System" (8).

Experiment 1 . Twenty rats weighing approximately $47 \mathrm{~g}$ were fed on a basal diet (CE-7 powder, Japan CLEA Inc., Tokyo) ad libitum for one week. Thereafter, the feeding pattern was shifted to meal-feeding at $08.00-09.00 \mathrm{hr}$ and at 21.00 $22.00 \mathrm{hr}$. At the end of this adaptation period, rats were divided into two groups having similar body weight, food intake and voluntary running activity. Both groups were meal-fed for an additional ten weeks, however, one of the two meals for each group was replaced by a sucrose-containing diet. The sucrose diet was prepared by adding sucrose to the basal diet at $35 \%$ concentration by weight. One group was provided with the sucrose diet at $08.00-09.00 \mathrm{hr}$ and the basal diet at 21.00-22.00 hr (Morning-Sucrose eaters; M-S eaters), and the reverse for the other group (Evening-Sucrose eaters; E-S eaters). Consequently, the timing of sucrose feeding was "Exercise $\longrightarrow$ Sucrose feeding $\longrightarrow$ Resting" for M-S eaters and "Resting $\longrightarrow$ Sucrose feeding $\longrightarrow$ Exercise" for E-S eaters. The sucrose content of the sucrose diet was based on the reports of $\operatorname{Krehl}(9)$ and Yudkin (10). These workers pointed out that sucrose consumption exceeding $20 \%$ of daily energy intake may be partly responsible for the prevalence of cardiovascular diseases in the U.S.A. In our previous study (7), when rats were meal-fed on a commercial powder diet daily twice at the same meal times as with this study, they consumed almost equal amounts of the diet at each meal. Therefore, it was assumed that $35 \%$ sucrose diet might provide approximately $20 \%$ of daily total energy intake.

Drinking water was available for $24 \mathrm{hr}$ throughout the feeding period. Body weight at $07.00 \mathrm{hr}$, food intake, and amounts of voluntary running were measured daily over the last ten weeks of the experimental period. The rhythm of voluntary running activity between 22.00 and $08.00 \mathrm{hr}$ was measured on three successive days in each week. At fourteen weeks of age, circadian variations of body weight were measured twice every two-hours at three-day intervals.

At the end of the experiment, at sixteen weeks of age, five rats from each group were killed by decapitation at 07.00 and $20.00 \mathrm{hr}$. Blood was collected and separated into plasma. Epididymal and perirenal fat pads, heart, liver, and soleus muscle were removed, weighed, and frozen at $-80^{\circ} \mathrm{C}$ until the assay of lipoprotein lipase [LPL, EC 3.1.1.3] activity. Liver total lipid was extracted (11) and determined gravimetrically. Plasma was determined for concentrations of free fatty acids(12), total 
cholesterol (13) and TG(14).

Tissue LPL activity was measured mostly according to the method of Gasquet and Pequignot(15). A substrate emulsion was prepared by mixing 1 vol of $10 \%$ intralipid ( $10 \mathrm{~g}$ of soybean oil, $1.2 \mathrm{~g}$ of egg lecithin, and $2.5 \mathrm{~g}$ of glycerol in $100 \mathrm{ml}$ of saline solution), 1 vol of fasting rat serum and 8 vol of $0.35 \mathrm{~m}$ Tris- $\mathrm{HCl}$ buffer $(7.5 \%$ bovine serum albumin, $\mathrm{pH} 8.1$ ). The substrate was activated by pre-incubating the emulsion at $37^{\circ} \mathrm{C}$ for $45 \mathrm{~min}$ before use. The preparation-activation procedure was carried out at every assay. Approximately $200 \mathrm{mg}$ of tissues were homogenized in a glass homogenizer with $10 \mathrm{ml}$ of $50 \mathrm{mM} \mathrm{NH}-\mathrm{NH}_{4} \mathrm{Cl}$ buffer containing 2 i.u. of heparin per ml, $\mathrm{pH} 8.1$. Four assay tubes per tissue were prepared by mixing $1 \mathrm{vol}$ of tissue homogenate and 1 vol of the activated substrate emulsion. They were incubated at $37^{\circ} \mathrm{C}$ with mild shaking and two pairs of tubes were removed at $5 \mathrm{~min}$ and $65 \mathrm{~min}$ of incubation time, respectively. After the incubation, free fatty acids were extracted using Dole's solution modified by adding $2 \mathrm{~N} \mathrm{H}_{2} \mathrm{SO}_{4}$ and determined by the micro-titration method $(16,17)$. Titration solution $(0.009 \mathrm{~N} \mathrm{NaOH})$ and indicator solution $(0.002 \%$ thymol blue) were prepared in redistilled isopropanol (18). As a blank, a mixture of 1 vol of the activated substrate emulsion and 1 vol of the buffer was incubated in the manner described above. The LPL activity of tissues, with the exception of liver, was inhibited by $95-99 \%$ with $0.5 \mathrm{M} \mathrm{NaCl}$ added to the incubation medium, therefore, the lipolytic activity measured was assessed to LPL activity (19). In liver, the degree of inhibition was $25 \%$. So liver LPL activity here contained hepatic TG lipase activity at about $75 \%$ of total activity.

Experiment 2. The rate of hepatic-intestinal TG production was estimated by determining plasma TG accumulation after administration of Triton WR-1339 to rats (20). Sixty rats were fed in the same manner as in experiment 1 . After 10 weeks of alternate meal-feeding on the basal diet and the sucrose diet, M-S eaters and E-S eaters had Triton ( $10 \%$ solution in saline) injected into the tail vein at a dose of $600 \mathrm{mg}$ per $\mathrm{kg}$ body weight (20). Nine to ten rats of each group were injected at $05.00 \mathrm{hr}$, and another 9-10 rats of each group received the injection at $18.00 \mathrm{hr}$. Four to five rats of both groups were killed by decapitation 1 and $2 \mathrm{hr}$ after injection, and plasma TG concentrations were determined (14). In both groups, the 5 remaining rats were killed without Triton at 05.00 and $18.00 \mathrm{hr}$ and served for controls. They were also used for the measurement of tissue LPL activity as described in experiment 1 . As data on tissue LPL activity were not significantly different between experiments 1 and 2, only the data from experiment 2 are shown in this paper.

Statistical analysis of the data was done by means of the Student's $t$-test.

\section{RESULTS}

\section{Experiment 1}

Weight gain and voluntary running activity (Table 1). During the 10 weeks of the experimental period, there was no significant difference in weight gain and 
Table 1. Changes in weekly weight gain and daily voluntary running activity of rats during 10 weeks of daily alternate meal-feeding on a basal diet and a $35 \%$ sucrose diet under controlled diurnal rhythm of voluntary running and resting (experiment 1).

M-S eaters and E-S eaters daily consumed a $35 \%$ sucrose diet at $08.00-09.00 \mathrm{hr}$ and at $21.00-22.00 \mathrm{hr}$, respectively, and a basal diet was provided at $21.00-22.00 \mathrm{hr}$ for M-S eaters and at $08.00-09.00 \mathrm{hr}$ for E-S eaters. Voluntary running in wheels was allowed only between $22.00-08.00 \mathrm{hr}$ for both groups. Other details of feeding conditions are shown in Fig. 1. Body weight and amounts of voluntary running were measured daily throughout the experimental period. Values are means $\pm S E$ of 10 rats for each group. Initial and final body weights were $130 \pm 6 \mathrm{~g}$ and $409 \pm 11 \mathrm{~g}$ for M-S eaters, and $130 \pm 8 \mathrm{~g}$ and $410 \pm 16 \mathrm{~g}$ for E-S eaters, respectively.

\begin{tabular}{|c|c|c|c|c|}
\hline \multirow{3}{*}{$\begin{array}{c}\text { Age } \\
\text { (weeks) }\end{array}$} & \multicolumn{2}{|c|}{ Weight gain } & \multicolumn{2}{|c|}{ Voluntary running activity } \\
\hline & M-S eaters & E-S eaters & M-S eaters & E-S eaters \\
\hline & \multicolumn{2}{|c|}{ (g per week) } & \multicolumn{2}{|c|}{ (km per day) } \\
\hline 6 & $46 \pm 3$ & $42 \pm 2$ & $7.2 \pm 0.5$ & $7.1 \pm 0.4$ \\
\hline 7 & $44 \pm 3$ & $48 \pm 3$ & $7.5 \pm 0.6$ & $7.4 \pm 0.5$ \\
\hline 8 & $34 \pm 2$ & $42 \pm 3^{a}$ & $8.3 \pm 0.6$ & $7.0 \pm 0.5$ \\
\hline 9 & $32 \pm 2$ & $29 \pm 2$ & $8.4 \pm 0.6$ & $9.4 \pm 0.6$ \\
\hline 10 & $25 \pm 2$ & $19 \pm 3$ & $8.2 \pm 0.6$ & $8.3 \pm 0.5$ \\
\hline 11 & $17 \pm 3$ & $25 \pm 5$ & $8.4 \pm 0.5$ & $7.7 \pm 0.7$ \\
\hline 12 & $22 \pm 2$ & $24 \pm 3$ & $4.9 \pm 0.4$ & $5.5 \pm 0.6$ \\
\hline 13 & $25 \pm 1$ & $18 \pm 3^{a}$ & $4.1 \pm 0.4$ & $4.1 \pm 0.8$ \\
\hline 14 & $16 \pm 4$ & $18 \pm 2$ & $4.6 \pm 0.5$ & $3.0 \pm 0.3^{\mathrm{a}}$ \\
\hline 15 & $17 \pm 1$ & $11 \pm 3^{\mathrm{a}}$ & $3.3 \pm 0.4$ & $3.1 \pm 0.4$ \\
\hline
\end{tabular}

${ }^{\text {a }}$ Significantly different from M-S eaters $(p<0.05)$.

voluntary running activity in relation to the timing of sucrose feeding. During 6 to 11 weeks of age, rats showed a high voluntary activity with $7-9 \mathrm{~km} / 10 \mathrm{hr}(22.00$ $08.00 \mathrm{hr}$ ) per day, but a marked decrease of the activity was observed at 12 weeks of age. This is probably due to the decrease in voluntary activity that occurs with age (21-24). The total amount of voluntary running throughout the 10 weeks of the experiment was $455 \pm 67$ (mean $\pm \mathrm{SE}$ ) $\mathrm{km}$ for M-S eaters and $439 \pm 54 \mathrm{~km}$ for E-S eaters.

Food consumption and intake of energy from sucrose (Table 2). In the preexperimental period at 5 weeks of age when all animals were provided with the basal diet at each meal time, food intake per week was $63 \pm 2 \mathrm{~g}$ for feeding $08.00-09.00 \mathrm{hr}$ and $62 \pm 2 \mathrm{~g}$ for feeding at $21.00-22.00 \mathrm{hr}$. The ratio of food intake with $1: 1 / 08.00$ $09.00 \mathrm{hr}: 21.00-22.00 \mathrm{hr}$ agrees with our previous observation(7). During the alternate meal-feeding on the two diets thereafter, however, animals preferred nearly double the sucrose diet to the basal diet. The energy from sucrose was about $25 \%$ of the total energy intake in both groups. There was no significant difference in the consumption of either the sucrose diet or the basal diet due to the feed timing for 
Table 2. Weekly food intake and intake of energy from sucrose in rats during 10 weeks of daily alternate meal-feeding on a basal diet and a $35 \%$ sucrose diet under controlled diurnal rhythm of voluntary running and resting (experiment 1 ).

See Fig. 1 and legends to Table 1. Food consumption for each meal time was measured daily throughout the feeding period.

\begin{tabular}{|c|c|c|c|c|c|c|c|c|}
\hline \multirow{4}{*}{$\begin{array}{c}\text { Age } \\
\text { (weeks) }\end{array}$} & \multicolumn{4}{|c|}{ M-S eaters } & \multicolumn{4}{|c|}{ E-S eaters } \\
\hline & \multicolumn{2}{|c|}{ Meal time (hr) } & \multirow{3}{*}{$\begin{array}{c}\text { Total } \\
\text { (g) }\end{array}$} & \multirow{3}{*}{$\begin{array}{c}\text { Energy } \\
\text { from } \\
\text { sucrose } \\
(\%)\end{array}$} & \multicolumn{2}{|c|}{ Meal time (hr) } & \multirow{3}{*}{$\begin{array}{c}\text { Total } \\
\text { (g) }\end{array}$} & \multirow{3}{*}{$\begin{array}{c}\text { Energy } \\
\text { from } \\
\text { sucrose } \\
(\%)\end{array}$} \\
\hline & $\begin{array}{r}08.00- \\
09.00\end{array}$ & $\begin{array}{r}21.00- \\
22.00\end{array}$ & & & $\begin{array}{r}08.00 \\
09.00\end{array}$ & $\begin{array}{r}21.00- \\
22.00\end{array}$ & & \\
\hline & $\begin{array}{c}\text { Sucrose } \\
\text { diet } \\
\text { (g) }\end{array}$ & $\begin{array}{c}\text { Basal } \\
\text { diet } \\
(\mathrm{g})\end{array}$ & & & $\begin{array}{c}\text { Basal } \\
\text { diet } \\
(\mathrm{g})\end{array}$ & $\begin{array}{c}\text { Sucrose } \\
\text { diet } \\
\text { (g) }\end{array}$ & & \\
\hline 6 & $93 \pm 4$ & $54 \pm 3$ & $149 \pm 5$ & 25 & $60 \pm 3$ & $85 \pm 3$ & $145 \pm 4$ & 23 \\
\hline 7 & $105 \pm 4$ & $61 \pm 3$ & $166 \pm 5$ & 25 & $71 \pm 2$ & $102 \pm 5$ & $174 \pm 6$ & 23 \\
\hline 8 & $113 \pm 4$ & $64 \pm 2$ & $178 \pm 4$ & 25 & $69 \pm 3$ & $112 \pm 3$ & $181 \pm 3$ & 24 \\
\hline 9 & $115 \pm 4$ & $66 \pm 3$ & $181 \pm 4$ & 25 & $63 \pm 2$ & $115 \pm 4$ & $177 \pm 4$ & 25 \\
\hline 10 & $116 \pm 6$ & $61 \pm 3$ & $176 \pm 4$ & 26 & $63 \pm 3$ & $113 \pm 4$ & $176 \pm 3$ & 25 \\
\hline 11 & $116 \pm 6$ & $61 \pm 4$ & $176 \pm 4$ & 26 & $65 \pm 3$ & $118 \pm 4$ & $183 \pm 5$ & 26 \\
\hline 12 & $112 \pm 3$ & $51 \pm 4$ & $163 \pm 2$ & 27 & $60 \pm 3$ & $105 \pm 3$ & $165 \pm 4$ & 25 \\
\hline 13 & $108 \pm 4$ & $63 \pm 4$ & $171 \pm 5$ & 25 & $55 \pm 4$ & $107 \pm 5$ & $162 \pm 4$ & 26 \\
\hline 14 & $117 \pm 4$ & $54 \pm 5$ & $171 \pm 6$ & 27 & $60 \pm 4$ & $109 \pm 5$ & $168 \pm 4$ & 25 \\
\hline 15 & $98 \pm 5$ & $49 \pm 5$ & $148 \pm 5$ & 26 & $54 \pm 5$ & $91 \pm 4$ & $144 \pm 5$ & 25 \\
\hline Total & $1,094 \pm 32$ & $585 \pm 27$ & $1,679 \pm 28$ & $26^{a}$ & $618 \pm 19$ & $1,057 \pm 21$ &, $675 \pm 25$ & $25^{\mathrm{a}}$ \\
\hline
\end{tabular}

Values are means $\pm \mathrm{SE}$ of 10 rats for each group. ${ }^{\mathrm{a}}$ Mean.

the two diets.

Diurnal variation of voluntary running (Fig. 2). The voluntary running activity was high either after the evening meal time or before the morning meal time, and it was low around $04.00 \mathrm{hr}$. A relatively high activity after the evening meal time was kept longer in E-S eaters than in M-S eaters from week 1 through week 10. However, the rhythm of activity between the groups was basically similar.

Diurnal variation of body weight (Fig. 3). The pattern of diurnal variation of body weight at 14 weeks of age was almost equal between the groups. The degree of weight gain of both groups after either the sucrose meal or the basal meal was equal due to the similar consumption of each diet by the two groups (Table 2). The amount of weight gain was greater after the sucrose meal than after the basal meal in both groups, which was due to a larger intake of the sucrose diet than of the basal diet. However, the rate of weight decline after each meal time was markedly greater during the exercise period than during the resting period. Weight reduction during the $10 \mathrm{hr}$ following the sucrose meal was significantly greater in E-S eaters $(19 \pm 1 \mathrm{~g})$ 


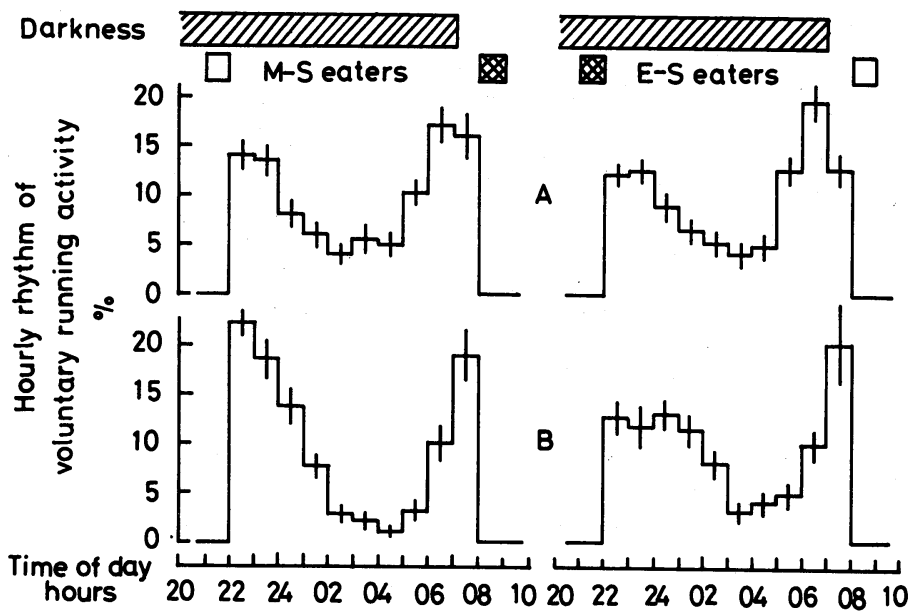

Fig. 2. Hourly rhythm of voluntary running activity of rats during 10 weeks of daily alternate meal-feeding on a basal diet and $35 \%$ sucrose diet under controlled diurnal rhythm of voluntary running and resting (experiment 1). See Fig. 1 and legends to Table 1. Five cages were used for the determination of the hourly rhythm of voluntary running activity. Each experimental group of 10 rats was divided in two. Measurements were done for an initial 3 successive days of the 1st week of measurement with $5 \mathrm{M}-\mathrm{S}$ eater rats and then with $5 \mathrm{E}-\mathrm{S}$ eater rats for the final 3 days of the week. In the same way, the rhythm of activity of the remaining 5 rats of both groups was determined in the following week. This measurement cycle was repeated 5 times throughout the experimental period. Thus, the data are expressed as means (horizontal lines) and SE (vertical bars) of 10 rats for each group per two weeks. $\square$, meal time for a basal diet. meal time for a $35 \%$ sucrose diet. A: Week 1-2. B: Week 9-10.

than in M-S eaters $(8 \pm 1 \mathrm{~g})(p<0.001)$.

Organ and tissue weight (Table 3). As there was no significant difference in organ and tissue weight between the rats killed at 07.00 and $20.00 \mathrm{hr}$, data were pooled in each group. The feed timing for the two diets did not cause any significant difference in the weights of several organs, skeletal muscles and epididymal and perirenal adipose tissues.

Plasma lipid (Table 4). M-S eaters did not show a significantly higher concentration of plasma free fatty acids either at the two time points or on the average as compared with E-S eaters. Plasma concentration of total cholesterol was not significantly higher in M-S eaters at $07.00 \mathrm{hr}$ and significantly lower at $20.00 \mathrm{hr}$ as compared to E-S eaters. The effect of the timing of sucrose feeding on plasma TG levels was significant. At either time point, the concentration of plasma TG was higher in M-S eaters than in E-S eaters. The difference between the groups in both the values at $07.00 \mathrm{hr}$ and the averaged values of the two time points was statistically significant $(p<0.05)$. 


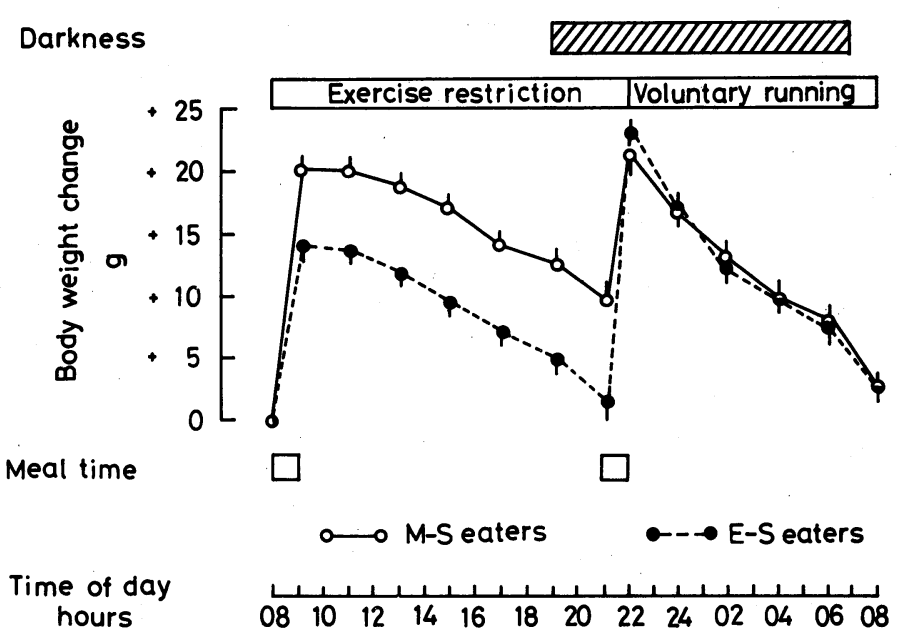

Fig. 3. Diurnal variation of body weight of rats at the 8 th week of experiment with daily alternate meal-feeding on a basal diet and a $35 \%$ sucrose diet under controlled diurnal rhythm of voluntary running and resting (experiment 1 ). M-S eaters and E-S eaters consumed the sucrose diet at $08.00-09.00 \mathrm{hr}$ and at $21.00-22.00 \mathrm{hr}$, respectively, and the basal diet was provided at $21.00-22.00 \mathrm{hr}$ for M-S eaters and at $08.00-09.00 \mathrm{hr}$ for E-S eaters. Animals were allowed to voluntarily run in wheels only between $22.00-08.00 \mathrm{hr}$. Measurements were done twice at three-day intervals in the 8th week of the experiment. Data obtained from separate measurements were combined, and values were expressed as differences from the body weight obtained at $08.00 \mathrm{hr}$ on the 1 st day of each measurement. Each point and vertical bar represents the mean and SE of 10 rats for each group, respectively.

Liver total lipid. In M-S eaters, liver total lipid content was $63 \pm 9 \mathrm{mg} / \mathrm{g}$ at $07.00 \mathrm{hr}, 67 \pm 7$ at $20.00 \mathrm{hr}$ and $65 \pm 5$ on average, and, in E-S eaters, it was $54 \pm 6$, $65 \pm 9$ and $59 \pm 5$, respectively. The differences between the groups were not significant.

\section{Experiment 2}

Changes in food intake, weight gain, voluntary running activity and diurnal variation during the experimental period of 10 weeks were almost the same as those observed in experiment 1 . Final body weight was $397 \pm 8 \mathrm{~g}$ for M-S eaters and $389 \pm 7 \mathrm{~g}$ for E-S eaters.

Heptic-intestinal TG production rate (Fig. 4). The plasma TG concentration increased linearly during the two hours following Triton injection. The TG production rate for both groups was significantly higher during the post-absorptive period after the sucrose meal than during that after the basal meal. During the resting period, the TG production rate was significantly greater in $\mathrm{M}-\mathrm{S}$ eaters than in E-S eaters, however, it was equal for the two groups during the voluntary exercise period. 
Table 3. Weights of several organs, skeletal muscles and adipose tissues of rats after 10 weeks of daily alternate meal-feeding on a basal diet and a $35 \%$ sucrose diet under controlled diurnal rhythm of voluntary running and resting (experiment 1).

See Fig. 1 and lengends to Table 1. On the final day of the feeding period, each of 5 rats was killed at $07.00 \mathrm{hr}$ or at $20.00 \mathrm{hr}$ in both groups. There was no significant difference between the two time points in weight of organs and tissues within each group, and, therefore, values at the two time points were combined in every group.

\begin{tabular}{|c|c|c|c|c|}
\hline \multirow{2}{*}{ Tissue and organs } & \multicolumn{2}{|c|}{ M-S eaters } & \multicolumn{2}{|c|}{ E-S eaters } \\
\hline & (g) & (g/100 g B.W.) & (g) & (g/100 g B.W.) \\
\hline Liver & $14.25 \pm 0.55$ & $3.45 \pm 0.12$ & $13.78 \pm 0.54$ & $3.44 \pm 0.11$ \\
\hline Heart & $1.07 \pm 0.04$ & $0.26 \pm 0.11$ & $1.09 \pm 0.02$ & $0.27 \pm 0.01$ \\
\hline Kidneys & $2.41 \pm 0.06$ & $0.58 \pm 0.01$ & $2.43 \pm 0.09$ & $0.61 \pm 0.02$ \\
\hline Lungs & $1.42 \pm 0.06$ & $0.34 \pm 0.01$ & $1.34 \pm 0.01$ & $0.33 \pm 0.01$ \\
\hline Stomach & $1.85 \pm 0.05$ & $0.45 \pm 0.01$ & $1.48 \pm 0.16$ & $0.37 \pm 0.04$ \\
\hline Epididymal fat & $5.69 \pm 0.53$ & $1.36 \pm 0.09$ & $5.47 \pm 0.58$ & $1.34 \pm 0.12$ \\
\hline Perirenal fat & $8.08 \pm 1.40$ & $1.90 \pm 0.28$ & $7.73 \pm 1.09$ & $1.65 \pm 0.31$ \\
\hline Gastrocnemius $\mathrm{m}^{\mathrm{a}}$ & $2.54 \pm 0.08$ & $0.61 \pm 0.01$ & $2.57 \pm 0.07$ & $0.64 \pm 0.02$ \\
\hline Soleus $\mathrm{m}^{\mathrm{a}}$ & $0.17 \pm 0.007$ & $0.04 \pm 0.001$ & $0.15 \pm 0.006$ & $0.04 \pm 0.002$ \\
\hline
\end{tabular}

${ }^{a}$ Muscles from right legs. Values are means $\pm S E$ of 10 rats for each group.

Table 4. Concentration of plasma free fatty acids, total cholesterol and triacylglycerols of rats after 10 weeks of daily alternate meal-feeding on a basal diet and a $35 \%$ sucrose diet under controlled diurnal rhythm of voluntary running and resting (experiment 1).

See Fig. 1 and legends to Table 1. On the final day of the feeding period, each of 5 rats of both groups was killed at $07.00 \mathrm{hr}$ or at $20.00 \mathrm{hr}$.

\begin{tabular}{cccc}
\hline $\begin{array}{c}\text { Time of day } \\
(\mathrm{hr})\end{array}$ & $\begin{array}{c}\text { Free fatty acids } \\
(\mu \mathrm{eq} / \mathrm{liter})\end{array}$ & $\begin{array}{c}\text { Total cholesterol } \\
(\mathrm{mg} / 100 \mathrm{ml})\end{array}$ & $\begin{array}{c}\text { Triacylglycerol } \\
(\mathrm{mg} / 100 \mathrm{ml})\end{array}$ \\
\hline M-S eaters & & & \\
$07.00(5)$ & $746.8 \pm 88.7$ & $94.6 \pm 11.7$ & $181.4 \pm 16.5^{\mathrm{a}}$ \\
$20.00(5)$ & $615.2 \pm 174.8$ & $68.2 \pm 3.4$ & $179.5 \pm 33.3$ \\
Average (10) & $681.0 \pm 95.0$ & $81.4 \pm 7.2$ & $180.5 \pm 17.5^{\mathrm{a}}$ \\
E-S eaters & & & \\
$07.00(5)$ & $515.0 \pm 46.4$ & $76.0 \pm 1.7$ & $119.9 \pm 10.7$ \\
$20.00(5)$ & $410.6 \pm 76.3$ & $75.9 \pm 2.2$ & $122.1 \pm 33.7$ \\
Average (10) & $462.8 \pm 45.0$ & $76.0 \pm 1.3$ & $121.0 \pm 16.7$ \\
\hline
\end{tabular}

Values are means $\pm S E$, and the number of rats is shown in parentheses. ${ }^{\text {a }}$ Significantly different from the corresponding value for E-S eaters $(p<0.05)$. 


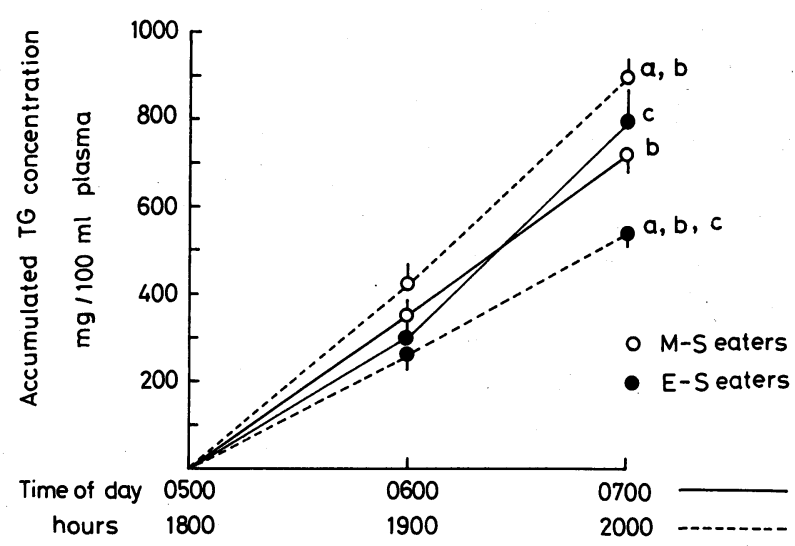

Fig. 4. Rate of hepatic-intestinal VLDL-TG production in rats after 10 weeks of daily alternate meal-feeding on a basal diet and a $35 \%$ sucrose diet under controlled diurnal rhythm of voluntary running and resting (experiment 2). Feeding schedules are indicated in Fig. 1 and legends to Table 1. On the final day of the experiment, $600 \mathrm{mg}$ of Triton WR-1339/kg of body weight was intravenously injected into each of the 9-10 rats of both groups at $05.00 \mathrm{hr}$ or at $18.00 \mathrm{hr}$, and subsequently each of the 4-5 rats of both groups were killed either one or two hours after the injection. To obtain pre-Triton plasma TG levels, the 5 rats of both groups were killed at $05.00 \mathrm{hr}$ or $18.00 \mathrm{hr}$ without the Triton injection. Data are expressed as changes in plasma TG concentration after Triton injection. Each point and vertical bar represents mean and SE, respectively. Mean values having the same superscript letters are significantly different (a: $p<0.01, \mathrm{~b}$ and $\mathrm{c}: p<0.05$ ).

Tissue LPL activity (Table 5). LPL activity of heart, soleus muscle, liver and epididymal fat pads was not significantly different between the two time points for each group. No significant difference between the groups was found in either the value at each time point or the mean value over the two time points. In perirenal fat pads, LPL activity of M-S eaters was significantly lower at $05.00 \mathrm{hr}$ than at $18.00 \mathrm{hr}$, and the activity at $18.00 \mathrm{hr}$ was significantly higher in M-S eaters than in E-S eaters. Epididymal adipose tissue showed similar responses to the two diets in LPL activity; in both groups, the activity was higher after the sucrose meal time than after the basal meal time. On the contrary, heart LPL activity was lower after the sucrose meal than after the basal meal. In the two experimental groups, no common change in the LPL activity of tissues due to physical activity was found. Among the tissues examined, mean LPL activity was higher in heart than in the adipose tissues, and low in the liver. Epididymal fat pads had a higher LPL activity than perirenal fat pads. 
Table 5. LPL activity of heart, soleus muscle, liver and adipose tissues of rats after 10 weeks of daily alternate meal-feeding on a basal diet and a $35 \%$ sucrose diet under a controlled diurnal rhythm of voluntary running and resting (experiment 2 ).

See Fig. 1 and legends to Table 1. M-S eaters and E-S eaters were meal-fed and controlled in their voluntary exercise similarly to those of experiment 1 . On the final day of the 10 weeks of the feeding period, each of 5 rats of both groups was killed at $05.00 \mathrm{hr}$ or at $18.00 \mathrm{hr}$. Activity in the liver included hepatic TG lipase activity at the level of about $75 \%$.

\begin{tabular}{|c|c|c|c|c|c|}
\hline \multirow{2}{*}{$\begin{array}{c}\text { Time of day } \\
\text { (hr) }\end{array}$} & Heart & Soleus $\mathrm{m}$. & Liver & Epididymal & Perirenal \\
\hline & \multicolumn{5}{|c|}{ ( $\mu$ eq free fatty acids released $/ \mathrm{hr}$ per $\mathrm{g}$ of tissue) } \\
\hline \multicolumn{6}{|l|}{ M-S eaters } \\
\hline $05.00(5)$ & $93.3 \pm 12.9$ & $29.3 \pm 5.1$ & $17.1 \pm 1.6$ & $53.3 \pm 14.2$ & $23.4 \pm 4.7^{\mathrm{a}}$ \\
\hline $18.00(5)$ & $60.6 \pm 5.3$ & $22.4 \pm 2.6$ & $18.7 \pm 1.4$ & $63.0 \pm 5.3$ & $48.5 \pm 4.0$ \\
\hline Average (10) & $77.0 \pm 8.5$ & $25.9 \pm 2.9$ & $17.9 \pm 1.0$ & $58.2 \pm 7.3$ & $36.0 \pm 5.1$ \\
\hline \multicolumn{6}{|l|}{ E-S eaters } \\
\hline $05.00(5)$ & $68.2 \pm 8.8$ & $26.7 \pm 2.7$ & $20.2 \pm 2.1$ & $64.2 \pm 13.1$ & $44.1 \pm 9.1$ \\
\hline $18.00(5)$ & $76.1 \pm 10.0$ & $27.4 \pm 2.0$ & $21.2 \pm 2.8$ & $51.8 \pm 3.5$ & $28.8 \pm 4.0^{\mathrm{a}}$ \\
\hline Average (10) & $72.1 \pm 6.4$ & $27.0 \pm 1.7$ & $20.7 \pm 1.7$ & $58.1 \pm 6.7$ & $36.5 \pm 5.4$ \\
\hline
\end{tabular}

Values are means $\pm \mathrm{SE}$, and the number of rats is shown in parentheses. ${ }^{\text {a Significantly }}$ different from $18.00 \mathrm{hr}$ for M-S eaters $(p<0.05)$.

\section{DISCUSSION}

Few studies have been conducted on rats by controlling not only the timing of sucrose feeding but also the daily rhythm of physical activity. As compared with our sucrose diet, higher sucrose-containing diets (65-75\% sucrose) have been widely used. Such differences in feeding conditions make it difficult to strictly compare our results with those of previous workers.

In the present study, rats of both groups consumed more of the $35 \%$ sucrose diet than the basal diet regardless of the timing of the sucrose meal. Ad libitum-fed sedentary rats have been reported to consume high-sucrose diets more (25) or less (26) than isocaloric starch diets, or consume both diets equally $(23,27)$. This discrepancy is probably due to the isocaloric nature of the diets as well as to the level of dietary sucrose. In sedentary rats meal-fed during two hours of the early dark period, Gardner and Reiser have observed a greater intake of a $54 \%$ sucrose diet than an isocaloric starch diet (28).

The protein level of the sucrose diet was lower than that of the basal diet in this study. However, in both experimental groups, almost equal amounts of protein were provided by the basal and sucrose diets; the total protein intake from the basal diet and the sucrose diet throughout the experimental period was $118 \mathrm{~g}$ and $136 \mathrm{~g}$ in M-S eaters and $125 \mathrm{~g}$ and $131 \mathrm{~g}$ in E-S eaters, respectively. This may indicate that rats consumed more sucrose diet than basal diet to maintain the protein require- 
ment. However, an increase in appetite with sucrose might be an another important reason why the sucrose diet showed a high rate of consumption by rats in this study. Percentages from sucrose in total energy intake exceeded our pre-estimation of $20 \%$; in fact, they were equally $25-26 \%$ for both groups. Voluntary running exercise is known to increase the food consumption of rats $(23,29)$. In this study, no difference was found between M-S eaters and E-S eaters in either the total consumption or individual consumptions of the two diets. This may be mostly due to equal voluntary activities of these groups.

As compared with ad libitum-fed and 24-hr freely exercised rats (7), rats of this study showed a considerably higher physical activity during 6-10 weeks of age, despite receiving restriction of the exercise period. In agreement with present data, food restriction such as fasting $(30,31)$, meal feeding for $2 \mathrm{hr}$ once a day $(7,32)$, or 40 -hr fasting after 8-hr feeding (22) has been reported to increase voluntary running activity of rats. However, Leveille and O'Hea (33) have reported in a longevity study that $2 \mathrm{hr}$ meal-fed rats exhibited a reduced voluntary running activity as compared with ad libitum-fed rats. Romsos and Leveille(5) have also observed that the spontaneous physical activity did not differ between meal-fed and ad libitum-fed rats housed in shoe-box cages on electronic activity meters. These disagreements might be derived from differences in the rats' cages, the method of activity measurement, age of rats, or other experimental conditions.

The running activity during the period of free access to wheels was very high after the $21.00-22.00 \mathrm{hr}$ meal and before the $08.00-09.00 \mathrm{hr}$ meal in both groups of this study. Such high activity during periods of pre- and post-meal times has been reported in rats(7) and gerbils(34). Ad libitum-fed rats have high voluntary activities during periods of frequent eating $(7,32,35,36)$.

No influence on plasma total cholesterol levels of the timing of the sucrose meal was noted, but a significant effect on plasma TG levels was observed. In experiment 1 of this study, M-S eaters, as compared with E-S eaters, showed significantly higher plasma TG concentrations. This seemed to be due to lower plasma TG removal and/or higher TG production in M-S eaters than in E-S eaters. To study the peripheral removal of plasma TG, an attempt was made to measure the LPL activity of several tissues used in this study. Tissue LPL activity was not significantly different between M-S eaters and E-S eaters in both experiments 1 and 2. This seems to suggest the rate of peripheral removal of plasma TG being similar in both groups. However, as Delorme and Harris have mentioned in their article (37), to evaluate the role of tissue LPL in the regulation of plasma TG, the functional and intracellular LPL must be separately measured, and the determination of the blood flow through each tissue is also needed. The assay system used here is unable to distinguish the functional from the intracellular LPL.

On the other hand, to determine the endogenous production of TG, Triton was utilized in the present study. Triton WR-1339 has been well established to inhibit by $90 \%$ the peripheral hydrolysis of VLDL-TG by LPL (38). Therefore, TG accumulation in the plasma after the Triton injection serves as a measure of the rate of 
production of VLDL-TG by the liver and intestine. As intestinal production contributes only $10-20 \%$ to total plasma TG $(39,40)$, post-Triton VLDL-TG accumulation in the present study might mainly reflect hepatic VLDL-TG production. In experiment 2 of this study, the Triton-induced increase in plasma TG between 18.00-20.00 hr was significantly higher in M-S eaters than in E-S eaters, but that during $05.00-07.00 \mathrm{hr}$ did not differ between the groups. Consequently, the timing of sucrose feeding might affect the TG production rate rather than the TG removal rate. Increasing amounts of fatty acids in the perfusing medium have been observed to stimulate production of VLDL by the perfused rat liver (41). Therefore, a relatively high plasma free fatty acid level in M-S eaters seems to support the increased production of TG in this group.

TG production by either M-S eaters or E-S eaters in the present experiment 2 was significantly higher at the period of post-absorption of the sucrose diet than at that of the basal diet. This seems to result from the fact that sucrose feeding stimulates secretion of VLDL-TG from the liver (42) and intestine (43). Production of TG by E-S eaters was almost equal to that by M-S eaters during the exercise period $(05.00-07.00 \mathrm{hr})$, although during this time E-S eaters were in the state of post-absorption of the sucrose diet. The mechanism(s) which suppressed production of TG by E-S eaters during the period following the sucrose meal might be concerned with the hormonal control of TG production. The elevation of plasma insulin has been demonstrated by Reaven et al. (44) to increase TG production, and glucagon excess has been shown by Eaton (45) to inhibit apoprotein formation in the liver. On the other hand, Winder et al. (46) have observed lower TG production after single fructose feeding of treadmill-exercise trained rats as compared with sedentary controls. Simonelli and Eaton(20) have also reported that chronic voluntary exercise with wheels decreases Triton-induced TG production in the fasting state in either hyperlipemic obese or non-lipemic thin Zucker rats. The latter workers also observed a decreased plasma glucagon level in the obese rats and an increased plasma insulin level in the thin rats after chronic exercise. In the present study, the long-term effect of voluntary running exercise might be almost equal for the two groups. However, as reviewed by Terjüng (47), plasma insulin decreases and plasma glucagon increases during and after exercise. Thus, the observed suppression of production of TG by E-S eaters during the physically active period following the sucrose diet might be caused by an exercise-induced reduction of the plasma insulin to glucagon ratio.

In the present study, although almost equal amounts of the sucrose diet were consumed by the two experimental groups of animals, E-S eaters lost significantly more weight than did M-S eaters during the fasting period following the sucrose meal. Thus, in E-S eaters, which had the option of voluntary running after the sucrose meal, the utility of sucrose might be greater for energy supply and lesser for lipogenesis as compared with M-S eaters. This might also relate to the different plasma TG levels observed between the groups.

LPL activities in the heart, muscle and adipose tissue have been reported to be Vol. 28, No. 3, 1982 
influenced by exercise (48-50). In this study, however, the two groups showed almost equal running activity throughout the feeding period. This might result in a similar LPL activity in M-S eaters and E-S eaters. Observed differences in tissue LPL activity between the physically active and inactive periods might reflect more the influence of the nature of the preceding diet than the effect of physical activity. In both animal groups of this study, the LPL activity of the two adipose tissues was significantly higher at the post-absorption period of the sucrose diet than at that of the basal diet. In contrast, cardiac LPL activity showed a reverse response of adipose tissue to the sucrose diet in both groups.

In conclusion, the present study has clearly demonstrated that the hyperlipemic effect of sucrose can be suppressed by feeding sucrose at a time which is followed by a physically active period. We thought that this might be largely due to the suppressive effect of physical activity on hepatic-intestinal TG production. In our experiments, no effect of tissue LPL activity on lowering sucrose-induced hyperlipemia was shown. It seems worth emphasizing that the timing of nutrient feeding and the rhythm of physical activity would be involved strongly in the regulation of lipid metabolism.

This work was presented in part at the 64th Annual Meeting of the Federation of American Societies for Experimental Biology, Anaheim, California, April, 1980. The abstract published in Fed. Proc., 39, 290 (1980). This work was partly supported by the U.S.-Japan Cooperative Medical Science Program on Malnutrition.

\section{REFERENCES}

1) Tepperman, H. M., and Tepperman, J. (1964): Adaptive hyperlipogenesis. Fed. Proc., 23, 73-75.

2) Welch, J. (1968): Effect of intermittent feeding on body composition of mice. Lab. Animal Care, 18, 596-601.

3) Nelson, W., Cadotte, L., and Halberg, F. (1973): Circadian timing of single daily "meal" affects survival of mice. Proc. Soc. Exp. Biol. Med., 144, 766-769.

4) Phillipens, K. M. H., Mayersbach, H. V., and Scheving, L. E. (1977): Effects of the scheduling of meal-feeding at different phases of the circadian system in rats. J. Nutr., 107, 176-193.

5) Romsos, D. R., and Leveille, G. A. (1977): Influence of meal frequency and timing on physical activity and body weights of rats. Proc. Soc. Exp. Biol. Med., 154, 457-460.

6) Sitren, H. S., and Stevenson, N. R. (1978): The effects of meal-feeding at different times of the day on daily changes in serum insulin, gastrin and liver enzymes in the rat. $J$. Nutr., 108, 1393-1401.

7) Suzuki, M., Hashiba, N., and Kanno, S. (1981): Effect of various feeding patterns on circadian rhythm of voluntary running activity in rats. Bull. Inst. Health and Sport Sci., Univ. Tsukuba, 4, 155-169.

8) Suzuki, M. (1980): Automated feeding apparatuses, in Nutritional Experiments Using Small Animals, ed. by Hosoya, N., Innami, S., and Gotoh, S., Daiichi-shuppan, Tokyo, pp. 36-39.

9) Krehl, W. A. (1977): The nutritional epidemiology of cardiovascular disease. Ann. N. Y. 
Acad. Sci., 300, 335-359.

10) Yudkin, J. (1972): Sucrose and cardiovascular disease. Proc. Nutr. Soc., 31, 331-337.

11) Folch, J., Lees, M., and Stanley, G. H. S. (1957): A simple method for the isolation and purification of total lipides from animal tissues. J. Biol. Chem., 226, 497-509.

12) Kawade, M. (1972): Free fatty acid. Rinsho Byori (Jpn. J. Clin. Pathol.), Suppl. 19, 66-73.

13) Zurkowski, P. (1964): A rapid method for cholesterol determination with a single reagent. Clin. Chem., 10, 451-453.

14) Fletcher, M. J. (1968): A colorimetric method for estimating serum triglycerides. Clin. Chim. Acta, 22, 393-397.

15) De Gasquet, P., and Pequignot, E. (1972): Lipoprotein lipase activities in adipose tissues, heart and diaphragm of the genetically obese mouse (ob/ob). Biochem. J., 127, 445-447.

16) Dole, V. P., and Minertz, H. (1960): Microdetermination of long-chain fatty acids in plasma and tissues. J. Biol. Chem., 235, 2595-2599.

17) Trout, D. L., Esters, E. H., Jr., and Friedberg, S. J. (1960): Titration of free fatty acids of plasma: a study of current methods and a new modification. J. Lipid Res., 1, 199-202.

18) Kaplan, A. (1970): A simple radioactive assay for triglyceride lipase. Anal. Biochem., 32, 218-225.

19) Ehnholm, C. H., Greten, H., and Brown, W. V. (1974): A comparative study of post heparin lipolytic activity and a purified human plasma triglyceride lipase. Biochim. Biophys. Acta, 360, 68-77.

20) Simonelli, C., and Eaton, R. P. (1978): Reduced triglyceride secretion: a metabolic consequence of chronic exercise. Am. J. Physiol., 234, E221-E227.

21) Slonaker, J. R. (1926): Long fluctuations in voluntary activity of the albino rats. Am. J. Physiol., 77, 503-508.

22) Yager, J. D., Jr., Lichtenstein, M. J., Bonney, R. J., Hopkins, H. A., Walker, P. R., Dorn, C. G., and Potter, V. R. (1974): Effects of various feeding and exercise regimens on rat growth and survival. J. Nutr., 104, 273-286.

23) Hebert, J. A., Kerkhoff, L., Bell, L., and Lopez-s', A. (1975): Effect of exercise on lipid metabolism of rats fed high carbohydrate diets. J. Nutr., 105, 718-725.

24) Goodrick, C. L. (1980): Effects of long-term voluntary wheel exercise on male and female Wistar rats. 1. Longevity, body weight, and metabolic rate. Gerontology, 26, 22-33.

25) Purdom, M. E., Mondragon, N. H., Pryor, W. W., and Gracy, R. W. (1972): Effect of carbohydrate on growth, plasma proteins and liver enzymes. J. Am. Diet. Assoc., 60, 394-398.

26) Varnell, T. R., and Chang, Y. (1972): Serosal accumulation of amino acids and hepatic lipid levels of rats fed several carbohydrates. Biochim. Biophys. Acta, 226, 445-452.

27) Ahrens, R. A., Kaul, L., and Hurney, M. E. (1971): Effect of dietary carbohydrate source in controlling voluntary physical activity in rats. J. Nutr., 101, 889-893.

28) Gardner, L. B., and Reiser, S. (1978): Effect of sucrose on adipose tissue and hepatic cyclic AMP levels in the rat. Nutr. Rep. Int., 17, 177-182.

29) Ring, G. C., Bosch, M., and Chu-Shek, L. (1970): Effects of exercise on growth, resting metabolism and body composition of Fischer rats. Proc. Soc. Exp. Biol. Med., 133, $1162-1165$.

30) Wald, G., and Jackson, B. (1944): Activity and nutritional deprivation. Proc. Natl. Acad. Sci.U.S.A., 30, 255-263.

31) Sclafani, A., and Rendel, A. (1978): Food deprivation-induced activity in normal and

Vol. 28, No. 3, 1982 
hypothalamic obese rats. Behav. Biol., 22, 244-255.

32) Krieger, D. T. (1974): Food and water restriction shifts corticosterone, temperature, activity and brain amine periodicity. Endocrinology, 95, 1195-1201.

33) Leveille, G. A., and O'Hea, E. K. (1967): Influence of periodicity of eating an energy metabolism in the rat. J. Nutr., 93, 541-545.

34) Roper, T. J. (1978): The effect of food deprivation on drinking and running in mongolian gerbils. Animal Behav., 26, 1264-1272.

35) Stephan, F. K., and Zucker, I. (1972): Circadian rhythm in drinking behavior and locomotor activity of rats are eliminated by hypothalamic lesions. Proc. Natl. Acad. Sci. U.S.A., 69, 1583-1586.

36) De Castro, J. M., Stoerzinger, A., Barkmeir, D., and Ellen, P. (1978): Medical septal lesions: Distribution of microregulatory patterns and circadian rhythmicity in rats. $J$. Comp. Physiol. Psycol., 92, 71-84.

37) Delorme, C. L. W., and Harris, K. L. (1975): Effect of diet on lipoprotein lipase activity in the rat. J. Nutr., 105, 447-451.

38) Otway, S., and Robinson, D. S. (1967): The use of a non-ionic detergent (Triton WR 1339) to determine rates of triglyceride entry into the circulation of the rat under different physiological conditions. J. Physiol. (London), 190, 321-332.

39) Risser, T. R., Reaven, G. M., and Reaven, E. P. (1978): Intestinal contribution to secretion of very low density lipoproteins into plasma. Am. J. Physiol., 234, E277-E281.

40) Holt, R. P., and Dominguez, A. A. (1980): Triton-induced hyperlipidemia: A model for studies of intestinal lipoprotein production. Am. J. Physiol., 238, G453-G457.

41) Richards, K. C., Ruderman, N. B., and Herrera, M. G. (1968): Effect of oleate concentration on its metabolism by the perfused rat liver. Biochim. Biophys. Acta, 152, 632-635.

42) Davis, R. A., Engelhorm, S. C., Pangburn, S. H., Weinstein, D. B., and Steinberg, D. (1979): Very low density lipoprotein synthesis and secretion by cultured rat hepatocytes. J. Biol. Chem., 254, 2010-2016.

43) Kelly, T. J., Holt, P. R., and Wu, A-L. (1980): Effect of sucrose on intestinal very lowdensity lipoprotein production. Am. J. Clin. Nutr., 33, 1033-1040.

44) Reaven, G. M., Lerner, R. L., Stern, M. P., and Farquhar, J. W. (1967): Role of insulin in endogenous hypertriglyceridemia. J. Clin. Invest., 46, 1756-1767.

45) Eaton, R. P. (1973): The hypolipemic action of glucagon in experimental endogenous lipemia in the rat. J. Lipid Res., 14, 312-318.

46) Winder, W. W., Booth, F. W., Fitts, R. H., and Holloszy, J. O. (1975): Effect of exercise on response of liver lipogenic enzymes to a high fructose diet. Proc. Soc. Exp. Biol. Med., 148, 1150-1154.

47) Terjüng, R. (1979): Endocrine response to exercise, in Exercise and Sport Sciences Reviews. Vol. 7, ed. by Hutton, R. S., and Miller, D. I., The Franklin Institute Press, Philadelphia, pp. 153-180.

48) Nikkilä, E., Torsti, P., and Penttilä, O. (1963): The effect of exercise on lipoprotein lipase activity of rat heart, adipose tissue and skeletal muscle. Metabolism, 12, 863-865.

49) Askew, E. W., Dohm, G. L., Huston, R. L., Sneed, T. W., and Dowdy, R. P. (1972): Responses of rat tissue lipases to physical training and exercise. Proc. Soc. Exp. Biol. Med., 141, 123-129.

50) Lithell, H., Hellsing, K., Lundqvist, G., and Malmberg, P. (1979): Lipoprotein-lipase activity of human skeletal muscle and adipose tissue after intensive physical exercise. Acta Physiol. Scand., 105, 312-315. 